\title{
Experimental study on the effect of toxin fractions isolated from hydatid cyst fluid of sheep on the cardiac muscles of mice
}

\author{
H.Kh. Ismail ${ }^{1}$, I.A. Al-Saleem ${ }^{2}{ }^{\circledR}$ and A.Y. Jasim ${ }^{3}$ \\ ${ }^{1}$ Department of pathology and poultry diseases, College of Veterinary Medicine, ${ }^{2}$ Department of Biology, College of Science, \\ University of Mosul, ${ }^{3}$ Department of animal production, Technical Institute Mosul, Northern Technical University, Mosul, \\ Iraq
}

\begin{tabular}{l} 
Article information \\
\hline Article history: \\
Received May 14, 2020 \\
Accepted July 14, 2020 \\
Available online June 24, 2021 \\
\hline Keywords: \\
Hydatid cyst \\
Toxin fractions \\
Raw fluid \\
Cardiomyocyte oedema \\
Cardiomyocyte necrosis \\
\hline Correspondence: \\
H.Kh. Ismail \\
hana_khismail@ yahoo.com
\end{tabular}

\begin{abstract}
The aim of this study was to investigate the effectiveness of hydatid cyst toxin fractions in mice. Fifty male mice were divided into five groups with 10 mice for each group the first group as control the second group was injected with toxin fractions at the concentrations $25 \mathrm{Mg} / \mathrm{ml}$ PBS, the third group are the mice that injected intraperitoneally with toxin fractions at the concentrations $25 \mathrm{Mg} / \mathrm{ml}$ PBS and treated with vitamin $\mathrm{E}$ at the concentration of $40 \mathrm{mg} / 100 \mathrm{~g}$ of feed, the fourth group was injected intraperitoneally with $1 \mathrm{ml}$ of raw fluid and the fifth group was injected intraperitoneally of $1 \mathrm{ml}$ of row fluid with the vitamin $\mathrm{E}$ at the concentration of $40 \mathrm{mg} / 100 \mathrm{gm}$ feed. The mice were sacrificed after 15 and 30days post injection, specimen of heart are fixed in 10\% neutral buffered formalin for histological techniques. The histopathological changes in cardiomyocyte were edema, infiltration of mononuclear cell and thickening of blood vessels wall with congestion in it. The results confirm that the toxin fraction have more effect than the raw fluid and that there is the regeneration effect of vitamin $\mathrm{E}$ on hydatid cyst cardiomyocyte.
\end{abstract}

DOI: 10.33899/ijvs.2020.127124.1463, (C2021, College of Veterinary Medicine, University of Mosul.

This is an open access article under the CC BY 4.0 license (http://creativecommons.org/licenses/by/4.0/).

\section{Introduction}

Hydatid cyst is a zoonotic helminthic malady caused by Echinococcus granulosus parasite, which is distributed in the Middle East $(1,2)$ in the stage of larva. The Echinococcus granulosus larva go along from the gastrointestinal via the portal system then to the, liver, lung and other organs, then they are converted to cyst leading the serious effects on these organs $(3,4)$. Phylogenetic analysis of E. granulosus detected that the isolated sequenced of it participate the highest similarity with other organisms (5). The hydatid cyst in lung were more fertile $55 \%$ in contrast to liver cysts $45 \%$. The wall of the cyst formed from the internal germinal layer, the middle laminated/lamellate layer, and the outer layer consist of fibers. Inflammatory response occur around the hydatid cyst was changeable and was recognized by loose regulated of mononuclear infiltrated with fibroblasts cells then densely regulated mononuclear along with fibroblasts cells; and an external layer of fibrous connective tissue. Fibroplasia and Calcification were distinguishing at this site (6).

There is a large number of histopathological changes were recognized in liver that infected with E. granulosus cysts involved changes in nucleus, degeneration in liver cells, a steatosis and necrosis. Increasing of Kupffer cells and fatty changes in many sections cirrhosis and liver cell degeneration was noticed, (6). Sections in lung presents infiltration of inflammatory cells around the necrotic cells (7). Hydatid cyst in heart is scarce (8), happened in approximately $0.5-2$ percent of all hydatid disease patients (9). Morbidity from heart echinococcosis in male is three times higher than that in female in which species cysts happened in approximately $60 \%$ of the specimen. Cardiac hydatid cyst notices in the left ventricle two to three fold more frequently than the right ventricles (8) and its presence 
in the left ventricular invasion by echinococcus is approximately $55-60 \%$ as it has the maximum myocardial mass and numerous blood supply the incidence of involvement of the interventricular septum is $5-9 \%$ of cases (10). The right ventricle is participating in approximately $15 \%$ of specimen, while the right atrium is participating in approximately $3-4 \%$ of specimen. Left ventricular hydatid cyst are situated subpericardium and scarcely blow up into the pericardial gap (11). The hydatid cyst in cardiac muscle can be recognized by two proceedings: discovery of the cyst and its recognition as echinococcus. The recognized is depending on X-ray, serological test, and magnetic resonance imaging echocardiography, computerized tomography (8).

The GSH is the essential antioxidant by chelating the superoxide beside the role of peroxidase (12) while the antioxidant function of Vitamin as a peroxyl radical scavenger that disconnect chain reactions, is well recognized by different scientists (13). The toxin fractions of hydatid cyst fluid and protoscoleces, isolated from hydatid cysts of sheep origin cause the raise of phagocytosis at the concentration of $2.5 \mu \mathrm{g}$ compared to $5 \mu \mathrm{g}$ in Protoscoleces and was the other way around in hydatid cyst fluid at $5 \mu \mathrm{g}$ (14) and also another study found that leucocytes are affected by toxin fractions at both concentrations $(2.5$ and $5 \mu \mathrm{g})$ at 3 and 15 days post infection when compared with control group (15). Immunologically another study found that treatment of mice with the toxin fractions caused a decrease in the percentage of lymphocytes in peripheral blood. Flowcytometric analysis confirm that T-cells in mice that treated with toxin had diminish membrane CD8, CD4 and CD3 density, and had increase percentages of $\mathrm{CD}^{+}$thymocytes expressing CD25and $\mathrm{CD}^{+}$splenocytes (16). The present research aims to investigate histopathological changes in cardiac muscles after intraperitoneal injection of hydatid cyst raw fluid and toxin fluid fractions.

\section{Materials and methods}

\section{Provenance of hydatid cysts}

Sheep hydatid cysts source were taken from affected livers of slaughtered sheep in Nineveh slaughter house of Iraq.

\section{Vitamin E}

Vitamin E used in a powder form was made by Shang Hang Veterinary pharmaceutical company and in a dose of $40 \mathrm{mg} / 100 \mathrm{gm}$ of feed (17).

\section{Isolation of cyst fluid}

Protoscoleces were aseptically removed from the cysts, depending on (18). The centrifuge was made at $7600 \mathrm{~g}$ (10000 rpm), by a cryocentrfuigation for approximately 10 minutes at $4^{\circ} \mathrm{C}$, then collection of supernatant (HCF) was made and preserved in sterilized vessels at $-20^{\circ} \mathrm{C}$ till used.

\section{Isolation of cyst fluid toxin fractions}

Cysts fluid fractions (CFFs) were isolated depending on the method of (15) by adding Ammonium sulphate to the fluid of the cyst $(49.35 \mathrm{gm} / 100 \mathrm{ml})$ and putting the fluid at $4{ }^{\circ} \mathrm{C}$ in the refrigerator for one day to precipitate the protein faster. The fluid was centrifuged. Then adding to the supernatant a similar volume of chloroform. After centrifugation two stratum were created. The chloroform stratum was detached and semi volume of methanol (chloroform to methanol 2: 1, v/v) was added and centrifuged under the same situation above-mentioned. The surface layer was dehydrated by rotary evaporator. The chloroform-methanol dissolvable fractions (CMDFs), or $\mathrm{TFs}$, were preserved at $-20^{\circ} \mathrm{C}$ till used. When we used it, we resolve it in scarce drizzle of chloroform and completed by phosphate buffer saline (PBS).

\section{Experimental styling}

Fifty healthy adult male albino mice at the age of 3-4 weeks were used in this experiment. It is divided in five major groups: The first group is a control, the second group is the mice that are injected with toxin fractions at the concentration $25 \mathrm{Mg} / \mathrm{ml}$ PBS in peritoneal cavity, the third group is the mice that are injected with toxin fractions at the concentration $25 \mathrm{Mg} / \mathrm{ml} \mathrm{PBS}$ and treated with vitamin E at the concentration of $40 \mathrm{mg} / 100 \mathrm{~g}$ of feed, the fourth group are the mice that injected by the $1 \mathrm{ml}$ of row infertile fluid and the fifth group are the mice that are injected with $1 \mathrm{ml}$ of a row of infertile fluid in peritoneal cavity with the vitamin $\mathrm{E}$ at the concentration of $40 \mathrm{mg} / 100 \mathrm{gm}$ feed.

The mice were sacrificed with diethyl ether inhalation after 15 and 30 days of treatment. Specimens of heart were rapidly removed parts of it fixed in $10 \%$ neutral buffered formalin for 3days and processed, then cleared in xylene, embedded in paraffin, sectioned and stained with HE $(19,20,21)$.

\section{Results}

This paper studied the effect of toxin fractions of hydatid cyst fluid on the mice myocardial muscle sections which stained with HE. The control group showed normal architecture of myocardial muscle (Figure 1). The histological examination of mice cardiac muscle treated with toxin fractions after 15 days showed several pathological changes includes, edema between muscle fibers with infiltration of mononuclear cells and generalized blood vessels congestion also degeneration and necrosis of myocardial cells observed (Figure 2-4).

The histopathological changes of mice cardiac muscles after 30 days of treatment with toxin fractions showed sever histological changes include sever edema between myocardial fibers disorganizer and discontinuation of cardiac muscle fiber (Figure 5), also there is hemorrhage in between the muscles fibers, sever infiltration of mononuclear 
inflammatory cells between the monocytes (Figure 6). Other section showed infiltration of mononuclear inflammatory cells in the pericardial layer also observed (Figure 7). Also degeneration and necrosis of myocardial muscle is obvious. On another hand the examination of histological of mice treated with hydatid cyst fluid only after 15 days showed degeneration and necrosis of myocardial muscle with pyknosis of nucleus, congestion of blood vessels with vasculitis (Figure 8).

While the histological changes after 30days of treatments showed infiltration of mononuclear inflammatory cells (Figure 9) also thickening of blood vessels, sever congestion degeneration and necrosis of myocardial muscles (Figure 10). Additionally, the histological changes of myocardial muscles of mice treated with toxin fractions and vitamin $\mathrm{E}$ after 15 and 30 days showed improvement in the histological appearance compared with those treated with toxin infraction and hydatid fluid, the myocardial muscle appeared with large nuclei this give induction of the regeneration process of myocytes, other changes showed little deference from control samples (Figure 11).

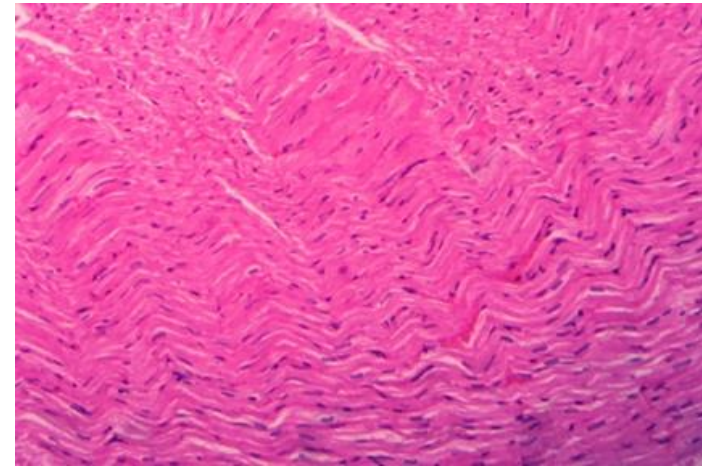

Figure 1: Micrograph of myocardial muscles I control mice showed normal architecture of muscle. (HE, 100X).

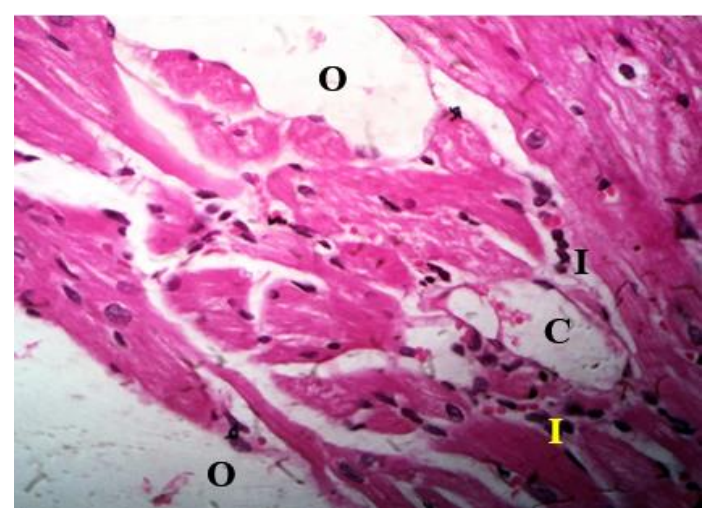

Figure 2: Micrograph of mice cardiac muscle after 15 days of treatment with toxin fraction showed edema (O) infiltration of mononuclear cells (I) blood vessels congestion (C) degeneration. (HE, 100X).

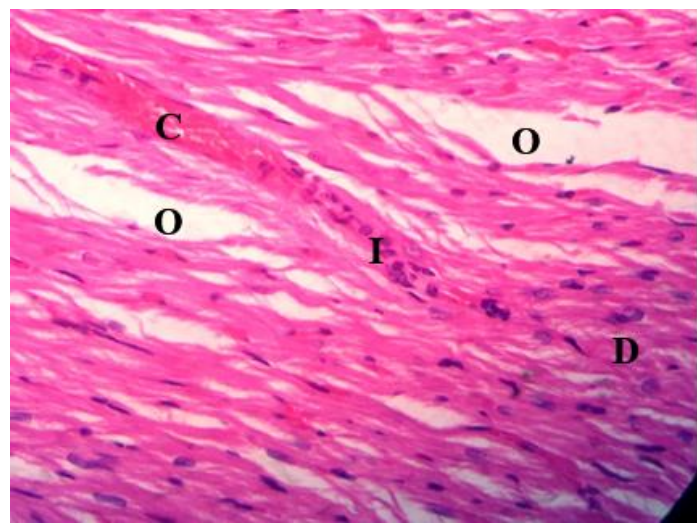

Figure 3: Micrograph of mice cardiac muscle after 15 days of treatment with toxin fraction showed edema (O) infiltration of mononuclear cells (I) congestion (C) degeneration and necrosis (D). (HE, 100X).

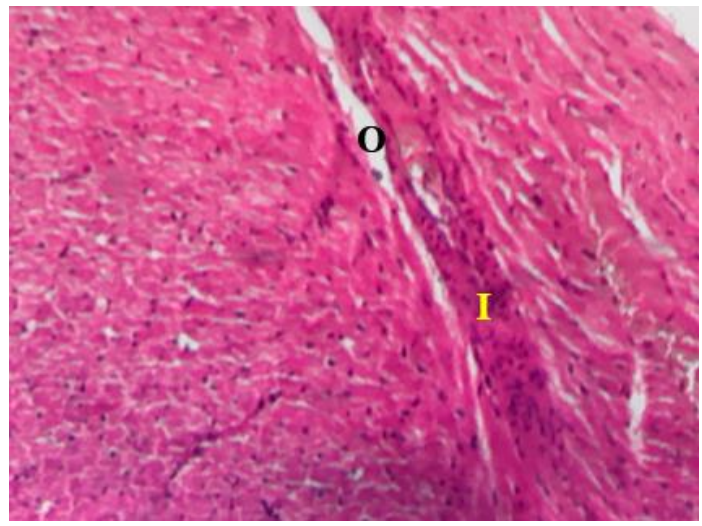

Figure 4: Micrograph of mice cardiac muscle after 15 days of treatment with toxin fraction showed edema (O) infiltration of mononuclear cells (I) also degeneration. (HE, 100X).

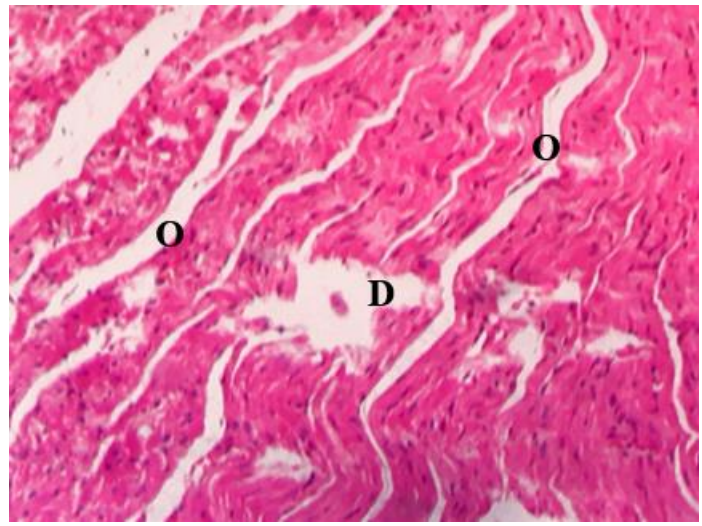

Figure 5: Micrograph of mice cardiac muscles after 30 days of treatment with toxin fraction showed sever edema (O), disorganizer and discontinuation (D). (HE, 100X). 


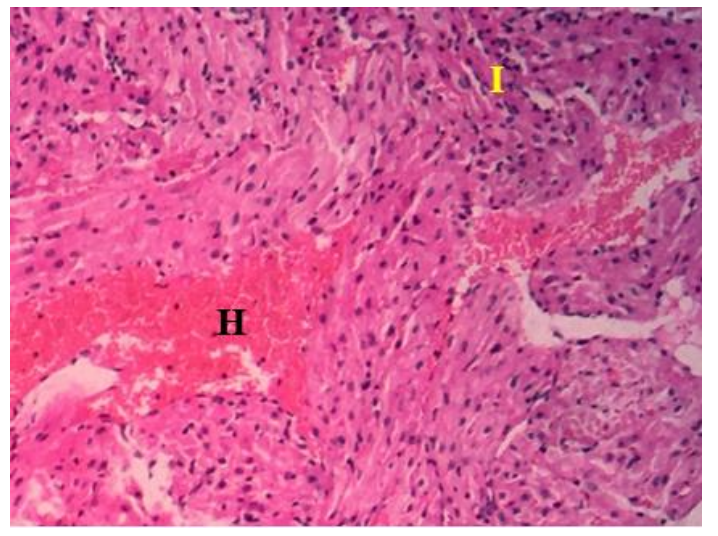

Figure 6: Micrograph of mice cardiac muscles after 30 days of treatment with toxin fraction showed Sever hemorrhage (H) sever infiltration of mononuclear inflammatory cells (I). (HE, 100X).

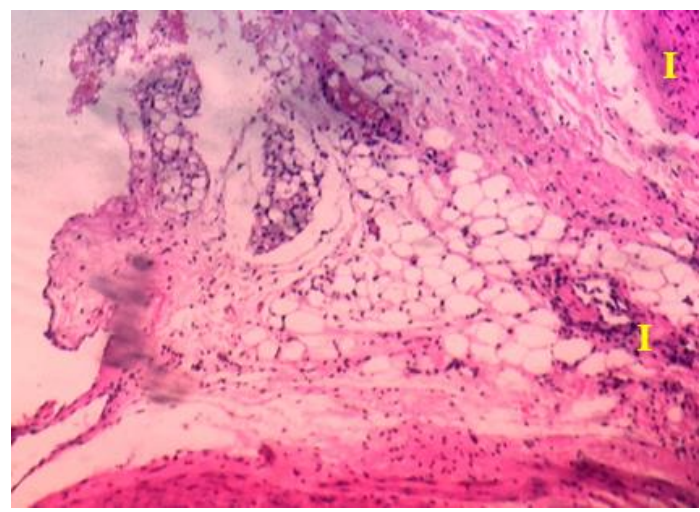

Figure 7: Micrograph of mice cardiac muscles after 30 days of treatment with toxin fraction showed infiltration of mononuclear inflammatory cells (I) in the pericardial layer. (HE, 100x).

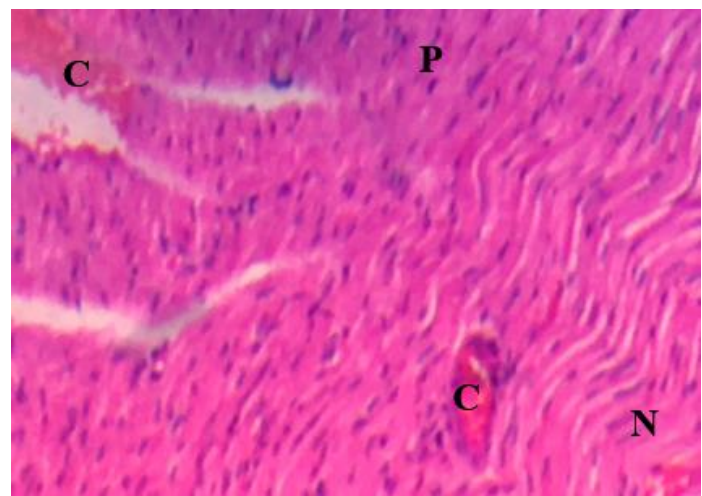

Figure 8: Micrograph of mice cardiac muscles after 15days of treatment with hydatid cyst fluid only showed degeneration and necrosis $(\mathrm{N})$ pyknosis of nucleus $(\mathrm{P})$, congestion of blood vessels (C) with vasculitis. (HE, 100x).

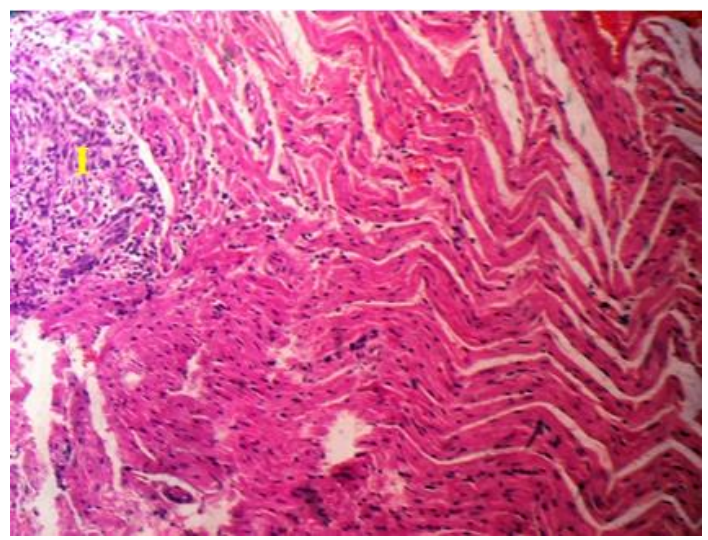

Figure 9: Micrograph of mice cardiac muscles after 30days of treatment with hydatid cyst fluid only showed infiltration of mononuclear inflammatory cells (I). (HE, 100X).

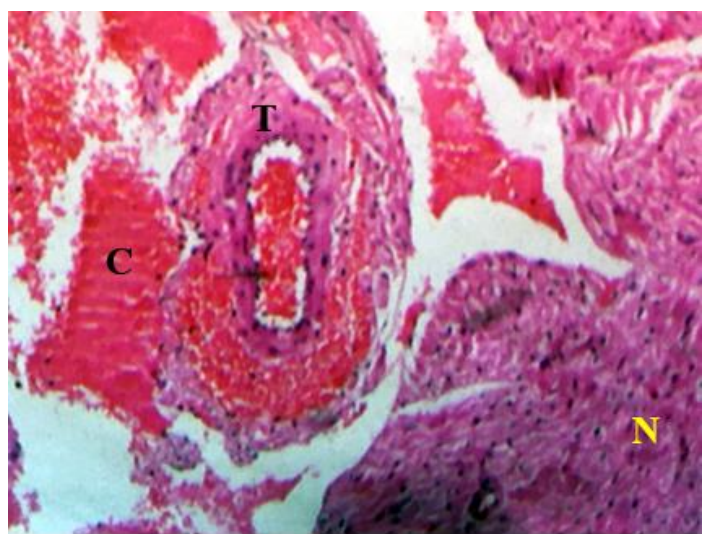

Figure 10: Micrograph of mice cardiac muscles after 30days of treatment with hydatid cyst fluid only showed thickening of blood vessel wall $(\mathrm{T})$, degeneration and necrosis $(\mathrm{N})$, congestion (C). (HE, 100X).

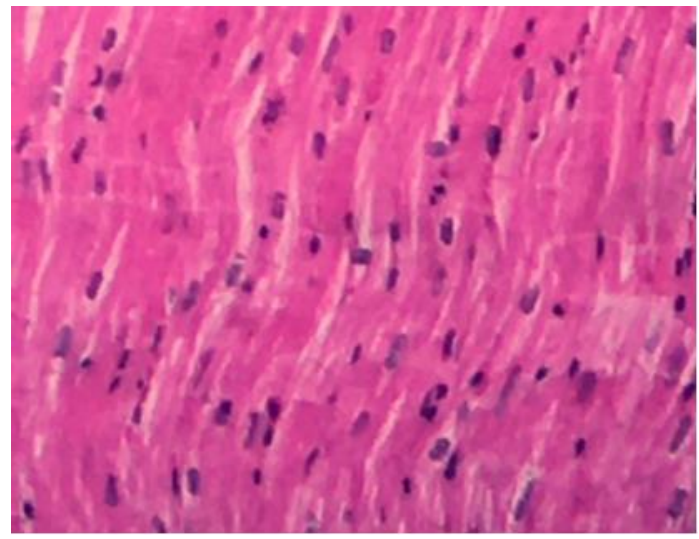

Figure 11: Micrograph of mice cardiac muscles after 30days of treatment with toxin fractions and vitamin $\mathrm{E}$ after showed the regeneration process of myocytes. (HE, 400x). 


\section{Discussion}

From our results we found that there is infiltration of inflammatory cells and necrosis of cardiomyocyte, this results were agreeing with other research on liver or abdominal goat or sheep in hydatid cyst that showed that there is infiltration of the adventitial layer with eosinophils, plasma cells and neutrophils. Additionally, to infiltration, the new gap between cyst wall and the liver tissue contained disorganized mesenchymal and fibroblasts (22). Also the results of this study found that there is a congestion in blood vessels and thickening in the wall of blood vessels this results was match with other previous study that found the glomerular tuft congestion, hyper-cellularity and hypertrophy of glomerular tuft after six weeks of infection by treatment with high viable protoscolices (1000 PS in 0.5 ml HBSS/rat) (23).

The lesions induced by hydatid cyst toxin fractions showed degeneration necrosis of myocardial muscle, these result confirmed that the toxin fractions and the raw fluid have the toxic effect on the myocardial muscle, this results agree with other study done by (24). Extravagant lipid oxidation changes the physical characteristics of the membrane of cells and can lead to destruction of cell membrane which cause release of large amount of phospholipid as well as covalent variations of nucleic acids and proteins and occurrence of hypoxia and the lymphocyte infiltration in response to the tissue injury (25) Vitamin E is a strong antioxidant specially for cell membranes. The free radicals formed by peroxidation of lipid are suggest to be concerning to membrane and plasma lipoproteins. Vitamin E conserve the cell membrane (26) and lead to regeneration of cardiomyocyte.

\section{Conclusions}

This study found that the hydatid cyst toxin fluid fraction and raw fluid have many histopathological effect on mice myocardial muscle, these effect represent by edema, thickening of blood vessels, congestion, infiltration of lymphocyte and the study confirm that using of vitamin E with hydatid cyst toxin fraction lead to regeneration of mice cardiomyocyte.

\section{Acknowledgments}

The researchers would like to thank college of veterinary medicine, University of Mosul for supplying facilities to perform the research.

\section{Conflict of interest}

The authors declare that there are no conflicts of interest.

\section{References}

1. Sadjjadi SM. Present situation of echinococcosis in the Middle East and Arabic North Africa. Parasitol Int. 2006;(55 Suppl):S197-202. DOI: 10.1016/j.parint.2005.11.030

2. Hidalgo C, Stoore C, Strull K, Franco C, Corrêa F, Jiménez M, Hernández M, Lorenzatto K, Ferreira H.B, Galanti N, Paredes R. New insights of the local immune response against both fertile and infertile hydatid cysts. PLoS One. 2019;14 (1):e0211542. DOI: 10.1371/journal.pone.0211542

3. Rokni MB. Echinococcosis /hydatidosis in Iran. Iran. J Parasitol. 2009;4:1-16. [available at]

4. Bodi F, Bhsheti S. Clinical presentation, localization and morphology of hepato- pulmonary hydatid cyst in patients operated in Tahran. World Appl Sci J. 2011;12(9):1544-1548. [available at]

5. Abdulla RG, Mageed SN, Obed CE, Jumaa JA. Molecular characterization of fertile hydatid cysts from the liver of the sheep and cows and associated environmental influence factors. Iraqi J Vet Sci. 2020;34(2):321-327. DOI: 10.33899/ijvs.2019.126036.1213

6. Beigh AB, Darzi1MM, Bashir S, kashani B, Shah SA. Gross and histopathological alterations associated with cystic echinococcosis in small ruminants. J Parasit Dis 2017;41(4):1028-1033. DOI: 10.1007/s12639-017-0929-z

7. Al-Aubaidi IK, Yaseen AN, Gathwan MA. Histopathological study of hepatic and pulmonary sheep's hydatidosis. Ann Trop Med Public Heal. 2017;22(IV):155. DOI: 10.36295 /ASRO.220413

8. Ohri S, Sachdeva A, Bhatia M, Shrivastava S. Cardiac hydatid cyst in left ventricular free wall. Echo Res Pract. 2015;2(1):17-19. DOI: 10.1530/ERP-14-0112

9. Beedkar A, ParikhR, Deshmukh P. Asymptomatic presentation of large cardiac hydatid. J Assoc Physicians India. 2017;65(2):98-99. [available at]

10. Maroto LC, Carrascal Y, Lopez MJ, Forteza A, Perez A, Zavanella C. Hydatid cyst of the interventricular septum in a 3.5-year-old child. Ann Thorac Surg. 1998;66(6):2110-2111.

11. Shehatha J, Alward M, Saxena P, Konstantinov IE. Surgical management of cardiac hydatidosis. Texas Heart Inst J. 2009;36:72-73. [available at]

12. Abd-Elbaky NA, Ali AA. Ahmed RA. Cardioprotective effect of simvastation doxorubicin-induced oxidative cardiotoxicity in rats. J Basic App Sci. 2010;6(1):29-38. DOI: 10.22159/ajpcr.2018.v11i7.24453

13. Burton GW, Ingold KU. Autoxidation of biological molecules. I. The antioxidant activity of vitamin $\mathrm{E}$ and related chain-breaking phenolic antioxidants in vitro. J Amer Chem Soc. 1981;103:6472-6477. DOI: 10.1021/ja00411a035

14. Salih NE, Al-Omar NS, Abdulla IT. Effect of toxin fractions isolated from protoscoleces and hydatid cyst fluid of sheep origin on phagocytosis in mice. Tikrit J Pure Sci. 2010;15(2):1-4. [available at]

15. Al-Omar NS. Effect of toxin fractions isolated from protoscoleces and hydatid cyst fluid of sheep origin on blood picture in mice. Tikrit J Pure Sci. 2011;16(1):34-37. [available at]

16. Janssen D, Rueda MC, De Ryck PH, Osuna A. Immunomodulation by hydatid cysts fluid toxin (Echinococcus granulosus). Parasit Immunol. 1997;19:149-160. DOI: 10.1046/J1365-3024/1997d01-194.x

17. Hassan S, Abed ER, Al-Hafez HK. Hydrogen peroxide-induced atherosclerosis in chickens: Effect of vitamin C. Iraqi J Vet Sci. 2000:249-270. [available at]

18. Smyth JD. In vitro culture of Echinococcus spp Proc. $13^{\text {th }}$ Int. Cong. Hydatid. Madrid: 1985:84-95.

19. Ismail HK. Histopathological alterations of male and female reproductive systems induced by alloxan in rats. Iraqi $\mathrm{J}$ Vet Sci. 2021;35(2):223-226. DOI: 10.33899/ijvs.2020.126626.1351

20. Barwarei $A B$ and Sadoon HS. Histopathological and some biochemical effects of platinum drug on the liver and kidney of pregnant mice Mus musculus and their embryos. Iraqi J Vet Sci. 2021(2):291-300. DOI: 10.33899/ijvs.2020.126793.1382 
21. Al-Khafaf AI, Ismail HK, Al-Saidya AM. Histopathological effects of experimental exposure to lead on nervous system in albino female rats. Iraqi J Vet Sci. 2021(1):45-48. DOI: 10.33899/ijvs.2019.126248.1273

22. BlantonR, Ernest M, Wachira T, Magambo K, Zeyhle E and Schantz P. Oxfendazole Treatment for Cystic Hydatid Disease in Naturally Infected Animals. Am Soc Microbiol. 1998;42(3):601-605. [available at]

23. El Sayed RA, Barghash SM, El-Alfy NM, Abou-Elnour BM, Sadek AM. Physiological, immuonological and histopathological comparison of echinococcus granulosus (G6) camel strain by different viability status using secondary cyst development in rat. Int J Adv Res. 2017;5(2):2119-2131. DOI: 10.21474/IJAR01/3385

24. Akhtar T, Mubashra T, Anwar Z. Haematological and biochemical changes in rabbits due to high doses of crude hydatid cyst fluid of sheep origin. Pakistan Vet J. 1998;18(2):82-86. [available at]

25. Gaschler MM. and Stockwell BR. Lipid peroxidation in cell death. Biochem Biophys Res Commun. 2017;482(3):419-425. DOI: 10.1016/j.bbrc.2016.10.086

26. Traber MG, Atkinson J. Vitamin E, antioxidant and nothing more. Free Radical Biol Med. 2007;43:4-15. DOI: 10.1016/j.freeradbiomed.2007.03.024

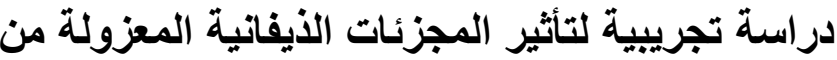 سائل الأكياس المائية في الأغنام على العضلات الفيلة القلبية

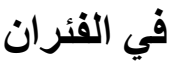

هناء خليل إسماعيل'، الهام عبالله علي' و أفراح يونس جاسم"

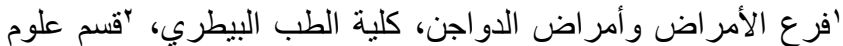

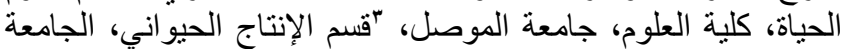

التقنية الثمالية، الموصل، العوم، العراقة الثوصن

الخلاصة

إن الهدف من هذه الدراسة هو تقصي تأثثر مجزئات الذيفان للسائل الذائل

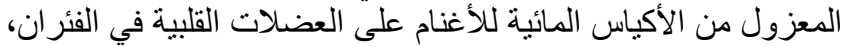

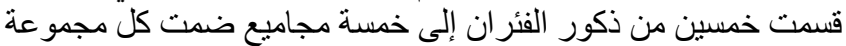

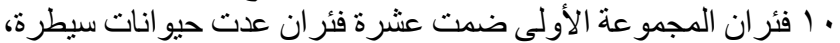

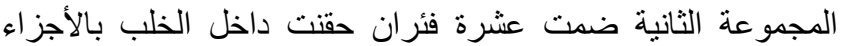

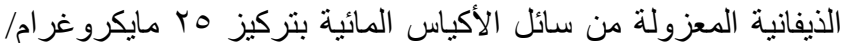

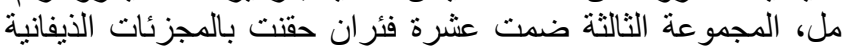

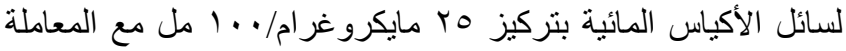

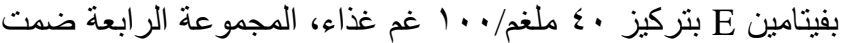

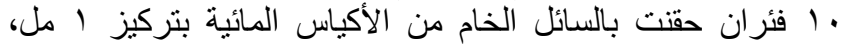

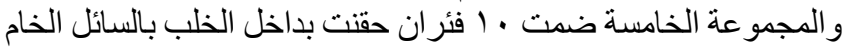

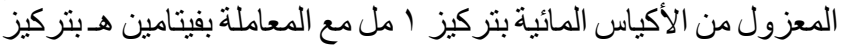

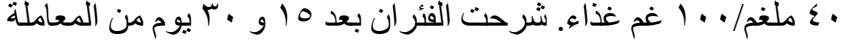
أخذت عينات من القلب وثبتت في محلول الفورمالين الداري المتعادل

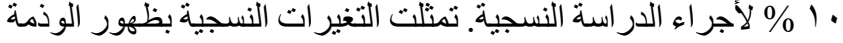

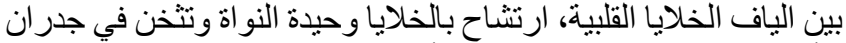

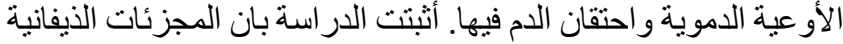

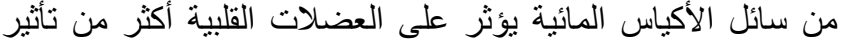

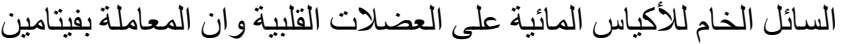

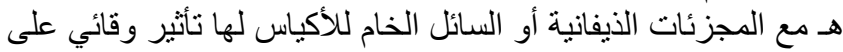
الخلايا العضلية القلبية. 